\title{
SUNFLOWER SEEDLINGS HYPERACCUMULATE SELENIUM
}

\author{
Farzaneh Garousi, ${ }^{1 *}$ Béla Kovács ${ }^{1}$ and Szilvia Veres ${ }^{2}$ \\ ${ }^{1}$ Faculty of Agricultural and Food Sciences and Environmental Management, Institute of Food Science, \\ University of Debrecen, H-4032 Debrecen Böszörményi út 138, Hungary \\ ${ }^{2}$ Faculty of Agricultural and Food Sciences and Environmental Management, Institute of Crop Sciences, \\ Department of Agricultural Botany, Crop Physiology and Biotechnology, University of Debrecen, \\ H-4032 Debrecen Böszörményi út 138, Hungary
}

(Received: October 25, 2017; accepted: March 27, 2018)

\begin{abstract}
Selenium (Se) is an essential element for animals and humans, but not plants. However, the capacity of some plants to accumulate and transform Se into bioactive compounds has important implications for human nutrition and health. In this study, sunflower (Helianthus annuus) and maize (Zea mays) seedlings were cultivated in soil to investigate the effect of different rates of sodium selenite (1-90 mg kg-1 soil) and sodium selenate (1-30 mg kg-1 soil) on absorption and translocation of Se and sulphur (S). Sodium selenate decreased growth of sunflower roots at all applied rates and of maize roots at the highest rate applied. In contrast, sodium selenite up to $30 \mathrm{mg} \mathrm{kg}^{-1}$ for sunflower and $3 \mathrm{mg} \mathrm{kg}^{-1}$ for maize resulted in increased shoot and root growth. An increase in Se concentration in soil resulted in an increase in Se and a decrease in S accumulation in roots and shoots of both maize and sunflower. Selenium translocation from roots to shoot was higher in sunflower than maize. Root-to-shoot translocation of Se was 5 to 30 times greater in sunflower and 0.4 to 3 times greater in maize in the sodium selenate than sodium selenite treatments. Sunflower, as a Se-hyperaccumulator with up to $1.8 \mathrm{~g} \mathrm{~kg}^{-1}$ in shoots (with no significant decrease in shoot biomass) can be a valuable plant in biofortification to improve animal/human nutrition, as well as in phytoremediation of contaminated sites to restore ecosystem services.
\end{abstract}

Keywords: Sodium selenite - sodium selenite - sunflower - maize - rhizobox

\section{INTRODUCTION}

Selenium (Se) is a naturally occurring chemical element found almost everywhere on earth. Deficiency or excess of Se can cause adverse effects on organisms [1, 12]. In the last decades, its physiological importance as a micronutrient fundamental to animal and human health has been established [11]. Selenium deficiency increases the risk of oxidative damage and important associated pathologies, i.e. cancer and HIV $[7,27]$.

Although essentiality of Se has been confirmed for bacteria, animals and humans, experimental attempts to identify its role in plants have not led thus so to recognizing Se as plant nutrient. However, the available reports showed that Se improved plant

\footnotetext{
*Corresponding author; e-mail address: farzaneh@agr.unideb.hu
} 
growth [31], increased tolerance to biotic and abiotic stresses [18, 29, 44] and was benefitial for other physiological parameters $[5,42,44]$.

Plant-based foods are the major dietary sources of Se in most countries in the world [35], and a mineral imbalance in the soil-plant system can lead to production of Se-deficient food with negative consequences for human and animal nutrition [15]. The awareness that the intake of Se by plants is the first step of Se entry into the human food chain could explain why biofortification with this element has received great attention. For instance, field treatments with Se or Se-rich compounds can be considered a safe, low-cost approach to achieving biofortification in Se-deficient areas $[2,4,13,20,25,32,33]$.

Although Se occurs in soil at different valence states [particularly Se(IV), $\mathrm{Se}(\mathrm{VI})$, $\mathrm{Se}(\mathrm{II})$ and $\mathrm{Se}(0)]$, Se can be absorbed by plants in the form of selenite and selenate [19]. Se shows some chemical similarities with sulphur; therefore, they can be taken up by sulphate transporters and metabolized in the sulphur metabolic pathways [39].

Despite a substantial literature on Se uptake by crops, such as wheat $[2,8,13,25$, 26], little attention was given to maize and sunflower, with only a few publications on Se uptake and assimilation in these plants [22]. Therefore, the aim of this study was to characterize the effects of two Se forms [sodium selenite $\left(\mathrm{Na}_{2} \mathrm{SeO}_{3}\right.$; active form: $\left.\mathrm{Se}^{\mathrm{IV}}\right)$ and sodium selenite $\left(\mathrm{Na}_{2} \mathrm{SeO}_{4}\right.$; active form: $\left.\left.\mathrm{Se}^{\mathrm{VI}}\right)\right]$ on the shoot and root growth and accumulation of Se in sunflower and maize.

\section{MATERIALS AND METHODS}

Sodium selenite and sodium selenate were obtained from Sigma-Aldrich Ltd. (Poole, UK). Nitric acid (69\% v/v ACS, VWR, Lutterworth, UK) hydrogen-peroxide (30\% $\mathrm{v} / \mathrm{v}$, Suprapure grade), and rhodium $\left(1,000 \mathrm{mg} \mathrm{L}^{-1}\right)$ for internal standard were obtained from Fluka (Poole, UK). The selenium $\left(1,000 \mathrm{mg} \mathrm{L}^{-1}\right.$ ) reference solution for $I C P-M S$ and ICP-OES calibration was supplied by Scharlau Chemie (Germany).

\section{Soil}

Calcareous Chernozem soil - a very dark mollic horizon (thick, brownish to blackish surface horizon with a significant accumulation of organic matter and high base saturation) [10] at the depth of $0-0.3 \mathrm{~m}$ was obtained from the Látókép Experimental Station (N: $47^{\circ} 33^{\prime}$, E: $21^{\circ} 27^{\prime}, 113-118 \mathrm{~m}$ above the sea level), University of Debrecen, Hungary. The soil properties (Table 1) were essentially the same as previously described by Nagy et al. [28]. No additional fertilization was applied. Selenium was supplemented to the soil as aqueous solution (prepared with distilled water) of sodium selenite $\left(\mathrm{Na}_{2} \mathrm{SeO}_{3}\right)$ or sodium selenate $\left(\mathrm{Na}_{2} \mathrm{SeO}_{4}\right)$ in concentrations of 0 (control), 1, 3, 10 and $30 \mathrm{mg} \mathrm{kg}^{-1}$ soil. In addition, sodium selenite concentration of 90 $\mathrm{mg} \mathrm{kg-1}$ soil was also tested. 
Table 1

Properties of calcareous Chernozem soil used

\begin{tabular}{|l|c|}
\hline $\mathrm{pH}(\mathrm{KCl})$ & 5.71 \\
\hline $\mathrm{pH}\left(\mathrm{H}_{2} \mathrm{O}\right)$ & 6.58 \\
\hline Soil texture category & loamy clay \\
\hline $\mathrm{CaCO}_{3}$ & $2.0 \mathrm{~g} \mathrm{~kg}^{-1}$ \\
\hline Organic matter & $35.4 \mathrm{~g} \mathrm{~kg}^{-1}$ \\
\hline $\mathrm{KCl}$-extractable $\mathrm{NO}_{3}-\mathrm{N}+\mathrm{NO}_{2}-\mathrm{N}$ & $8.04 \mathrm{mg} \mathrm{kg}^{-1}$ \\
\hline${ }^{1} \mathrm{AL}$-extractable $\mathrm{P}_{2} \mathrm{O}_{5}$ & $199 \mathrm{mg} \mathrm{kg}^{-1}$ \\
\hline AL-extractable $\mathrm{K}_{2} \mathrm{O}$ & $451 \mathrm{mg} \mathrm{kg}^{-1}$ \\
\hline AL-extractable $\mathrm{Na}$ & $332 \mathrm{mg} \mathrm{kg}^{-1}$ \\
\hline
\end{tabular}

${ }^{1} \mathrm{AL}: 0.1 \mathrm{~mol} \mathrm{dm}-3$ ammonium-lactate and $0.1 \mathrm{~mol} \mathrm{dm}^{-3}$ acetic-acid.

\section{Plant growth}

Sunflower (Helianthus annuus L. cv. Arena PR) as a dicotyledonous and maize (Zea mays L. cv. Norma SC) as a monocotyledonous species were chosen for experiments. Sunflower and maize seeds were surface-sterilised using $6 \%(\mathrm{v} / \mathrm{v}) \mathrm{H}_{2} \mathrm{O}_{2}$ for $2 \mathrm{~min}$, rinsed extensively with deionised water and were germinated geotropically between moist filter papers at $22{ }^{\circ} \mathrm{C}$. Sunflower seedlings with 1.5 - to 2.0 -cm long hypocotyl and maize seedlings with $2.5-$ to $3.0-\mathrm{cm}$ long coleoptile were placed into soil in rhizoboxes (length $24.5 \mathrm{~cm}$, width $10.5 \mathrm{~cm}$; depth $2 \mathrm{~cm}$ ) to easily monitor root development. Sunflower and maize plants were grown in a controlled-climate room. Relative humidity was maintained between $65-75 \%$, the light-dark cycle was $16-18$ $\mathrm{h}$ at respective $25-20{ }^{\circ} \mathrm{C}$ temperatures, and light intensity was $300 \mathrm{mmol} \mathrm{m}^{-2} \mathrm{~s}^{-1}$ during daytime.

In order to ensure uniform water supply to plants, wet fluted filter papers were placed at the bottom of the rhizoboxes before the soil was added. After planting seedlings in the soil, the transparent front wall of the rhizoboxes was covered with black foil. The rhizoboxes were placed at the 45 degree angle to force root growth along the transparent front wall of the box, thus allowing convenient monitoring of roots. The rhizoboxes were watered to weight daily.

\section{Sampling and measurements}

Root length was measured daily using millimeter paper. The experiment was harvested 6 days (maize) or 7 days (sunflower) after planting, when the longest roots reached the bottom of the rhizobox. Experiments were carried out in triplicates (three rhizoboxes), and every rhizobox had three seedlings. 
At the end of the experiment, shoots were separated from roots. These plant parts were dried at $70{ }^{\circ} \mathrm{C}$ until constant mass, then cooled to room temperature and weighed using an analytical scale (OHAUS, Switzerland). Dried samples (0.01, 0.5 or $1 \mathrm{~g}$, depending on the sample amounts) were homogenized and digested in the $\mathrm{HNO}_{3}-\mathrm{H}_{2} \mathrm{O}_{2}$ mixture [21]. Briefly, samples were kept in 1.5 or $10 \mathrm{~mL}$ concentrated $\mathrm{HNO}_{3}$ (according to the sample weight) overnight, and then heated to $60{ }^{\circ} \mathrm{C}$ for 45 min in a LABOR MIM OE 718/A block digestion apparatus. Following this first digestion step, $0.3,1.5$ or $3 \mathrm{~mL}$ of $\mathrm{H}_{2} \mathrm{O}_{2}(30 \% \mathrm{v} / \mathrm{v})$ was added to the samples, and digestion continued at $120^{\circ} \mathrm{C}$ for another $90 \mathrm{~min}$. After cooling the samples to room temperature, volume was adjusted to 5,25 or $50 \mathrm{~mL}$ with deionized water. Samples were then mixed by shaking and filtered through FILTRAK 388 filters.

\section{Transport factor (TF) calculation}

The capacity of sunflower and maize plants to transport and accumulate Se in roots and shoots was calculated using the transport factor (TF) as follows: $\mathrm{TF}=(\mathrm{Se}$ concentration $\times$ dry matter $)$ in shoot $/[($ Se concentration $\times$ dry matter $)$ in shoot $+($ Se concentration $\times$ dry matter) in roots], expressed as percentage.

\section{Quantification of selenium and sulphur}

Elemental analysis was carried out by inductively coupled plasma optical emission spectroscopy (ICP-OES) (Perkin Elmer OPTIMA 3300 DV, Bremen, Germany) for measurement of sulphur and inductively coupled plasma mass spectrometry (ICPMS) (Thermo Elemental X7, Bremen, Germany) for measurement of selenium. The concentration of sulphur was determined because selenium has chemical properties similar to sulphur. The instrument settings and parameters were the same as described previously [34].

\section{Statistical analysis}

All data were statistically analyzed using SPSS 19.0 software (2010). Standard deviation was calculated and analysis of variance (ANOVA) was performed on the data to determine the least significance difference (Tukey) between treatment means with the level of significance at $\mathrm{P} \leq 0.05$.

These rhizobox experiments were carried out in three independent and different times under identical conditions. 


\section{RESULTS}

\section{Root growth responses of sunflower and maize to sodium selenite and sodium selenate}

Sodium selenite enrichment caused an increase in the total root length of sunflower from average of $10.2 \mathrm{~cm}$ in the control to the maximum average of 22.1 in the $30 \mathrm{mg}$ $\mathrm{kg}^{-1}$ sodium selenite treatment after 7 days (data not shown). In maize, the average longest root $(22.5 \mathrm{~cm})$ was measured in the $3 \mathrm{mg} \mathrm{kg}^{-1}$ sodium selenite treatment in comparison with the control $(17 \mathrm{~cm})$ after 6 days. In both sunflower and maize, only the rate of $90 \mathrm{mg} \mathrm{kg}^{-1}$ sodium selenite inhibited significantly root elongation at the end of the experiment.

Sodium selenate enrichment caused severe and quick root growth inhibition. In sunflower, at $30 \mathrm{mg}$ sodium selenite $\mathrm{kg}^{-1}$, inhibition (compared with control) was significant even after 1 day, and no increase in total root length occurred after day 3; hence, after 7 days, total root length was 5-fold greater in control than at the highest sodium selenate rate. In contrast, total root length of maize seedlings was slightly (non-significantly) longer at $1 \mathrm{mg} \mathrm{kg}^{-1}$ sodium selenate than in the control after 6 days (data not shown). Moreover, maize total root length at the highest sodium selenate dose was $1 / 2$ that in the control after 6 days (compared with only $1 / 5$ of control in sunflower), suggesting greater resistance to sodium selenate in maize than sunflower.

Toxic doses of either sodium selenite at $90 \mathrm{mg} \mathrm{kg}^{-1}$ or sodium selenate at $30 \mathrm{mg}$ $\mathrm{kg}^{-1}$ caused decreases in root radius and root hair formation in sunflower and maize (data not shown).

\section{Effect of different Se forms on root and shoot dry weights in sunflower and maize}

There was a non-significant trend of increases in root and shoot mass with an increase in sodium selenite rates up to $30 \mathrm{mg} \mathrm{kg}^{-1}$ in sunflower (Table 2) and up to $3 \mathrm{mg} \mathrm{kg}^{-1}$ in maize roots (Table 3 ). In both sunflower and maize, there was a slight (non-significant) reduction in root and shoot mass in the treatment with the highest sodium selenite rate of $90 \mathrm{mg} \mathrm{kg}^{-1}$ compared with the control (Tables 2, 3).

Increasing sodium selenate rates did not significantly alter sunflower shoot mass, but there was a significant decline (compared with control) in root mass even at the low sodium selenate rate of $3 \mathrm{mg} \mathrm{kg}^{-1}$ soil (Table 2). In maize, there was no significant difference in root and shoot mass over the range of sodium selenate rates $(0-30$ $\mathrm{mg} \mathrm{kg}^{-1}$ soil) compared with the control (Table 3). In both sunflower and maize, rough comparisons suggested that sodium selenate was more toxic to root and shoot growth than sodium selenite. 
Table 2

Dry weight of sunflower shoots and roots (means $\pm \mathrm{SD}, \mathrm{n}=9$ ) after 7 days of Se treatments

\begin{tabular}{|c|c|c|c|c|}
\hline \multirow{2}{*}{$\begin{array}{c}\text { Applied Se compounds } \\
\left(\mathrm{mg} \mathrm{kg}^{-1} \text { soil }\right)\end{array}$} & \multicolumn{2}{|c|}{ Dry weight of shoots (mg/plant) } & \multicolumn{2}{c|}{ Dry weight of roots (mg/plant) } \\
\cline { 2 - 5 } & sodium selenite & sodium selenate & sodium selenite & sodium selenate \\
\hline 0 & $44 \pm 6^{\mathrm{a}}$ & $44 \pm 6^{\mathrm{a}}$ & $24 \pm 8^{\mathrm{a}}$ & $24 \pm 8^{\mathrm{a}}$ \\
\hline 1 & $47 \pm 3^{\mathrm{a}}$ & $43 \pm 15^{\mathrm{a}}$ & $24 \pm 4^{\mathrm{a}}$ & $19 \pm 3^{\mathrm{a}}$ \\
\hline 3 & $50 \pm 15^{\mathrm{a}}$ & $42 \pm 16^{\mathrm{a}}$ & $25 \pm 3^{\mathrm{a}}$ & $12 \pm 2^{\mathrm{b}}$ \\
\hline 10 & $51 \pm 6^{\mathrm{a}}$ & $41 \pm 9^{\mathrm{a}}$ & $29 \pm 8^{\mathrm{a}}$ & $8 \pm 2^{\mathrm{b}}$ \\
\hline 30 & $54 \pm 6^{\mathrm{a}}$ & $39 \pm 6^{\mathrm{a}}$ & $29 \pm 5^{\mathrm{a}}$ & $7 \pm 2^{\mathrm{b}}$ \\
\hline 90 & $35 \pm 2^{\mathrm{a}}$ & & $20 \pm 4^{\mathrm{a}}$ & \\
\hline
\end{tabular}

Significant differences among means in a column are indicated by different lower case letters based on the Tukey test $(\mathrm{p} \leq 0.05)$.

Table 3

Dry weight of maize shoot and roots (means $\pm \mathrm{SD}, \mathrm{n}=9$ ) after 6 days of Se treatment

\begin{tabular}{|c|c|c|c|c|}
\hline \multirow{2}{*}{$\begin{array}{c}\text { Applied Se compounds } \\
\left(\mathrm{mg} \mathrm{kg}^{-1} \text { soil }\right)\end{array}$} & \multicolumn{2}{|c|}{ Dry weight of shoots (mg/plant) } & \multicolumn{2}{c|}{ Dry weight of roots (mg/plant) } \\
\cline { 2 - 5 } & sodium selenite & sodium selenate & sodium selenite & sodium selenate \\
\hline 0.0 & $26 \pm 3^{\mathrm{a}}$ & $26 \pm 3^{\mathrm{a}}$ & $46 \pm 2^{\mathrm{a}}$ & $46 \pm 2^{\mathrm{a}}$ \\
\hline 1.0 & $28 \pm 12^{\mathrm{a}}$ & $27 \pm 3^{\mathrm{a}}$ & $49 \pm 10^{\mathrm{a}}$ & $62 \pm 12^{\mathrm{a}}$ \\
\hline 3.0 & $28 \pm 3^{\mathrm{a}}$ & $24 \pm 5^{\mathrm{a}}$ & $61 \pm 10^{\mathrm{a}}$ & $54 \pm 11^{\mathrm{a}}$ \\
\hline 10.0 & $24 \pm 1^{\mathrm{a}}$ & $23 \pm 5^{\mathrm{a}}$ & $46 \pm 13^{\mathrm{a}}$ & $42 \pm 22^{\mathrm{a}}$ \\
\hline 30.0 & $21 \pm 6^{\mathrm{a}}$ & $14 \pm 2^{\mathrm{a}}$ & $43 \pm 3^{\mathrm{a}}$ & $31 \pm 2^{\mathrm{a}}$ \\
\hline 90.0 & $14 \pm 2^{\mathrm{a}}$ & & $40 \pm 1^{\mathrm{a}}$ & \\
\hline
\end{tabular}

Significant differences among means in a column are indicated by different lower case letters based on the Tukey test $(\mathrm{p} \leq 0.05)$.

\section{Effect of different Se forms on Se and S accumulation in shoots and roots of sunflower and maize}

Selenium concentration and content in both roots and shoots significantly increased with increasing the rates of applied Se in either form in sunflower and maize (Tables $4,5)$. This increase was greater in sunflower than maize at different concentrations of the two Se forms. Supply of sodium selenate resulted in higher tissue Se concentrations than the supply of selenite. Compared with maize, shoot Se concentration in sunflower was 2.2-fold higher in the sodium selenate treatment, and 6.3-fold higher in the sodium selenite treatment. Correspondingly, sunflower shoots accumulated greater total Se amounts than maize, and accumulated more Se in the sodium selenate than sodium selenite treatments. 


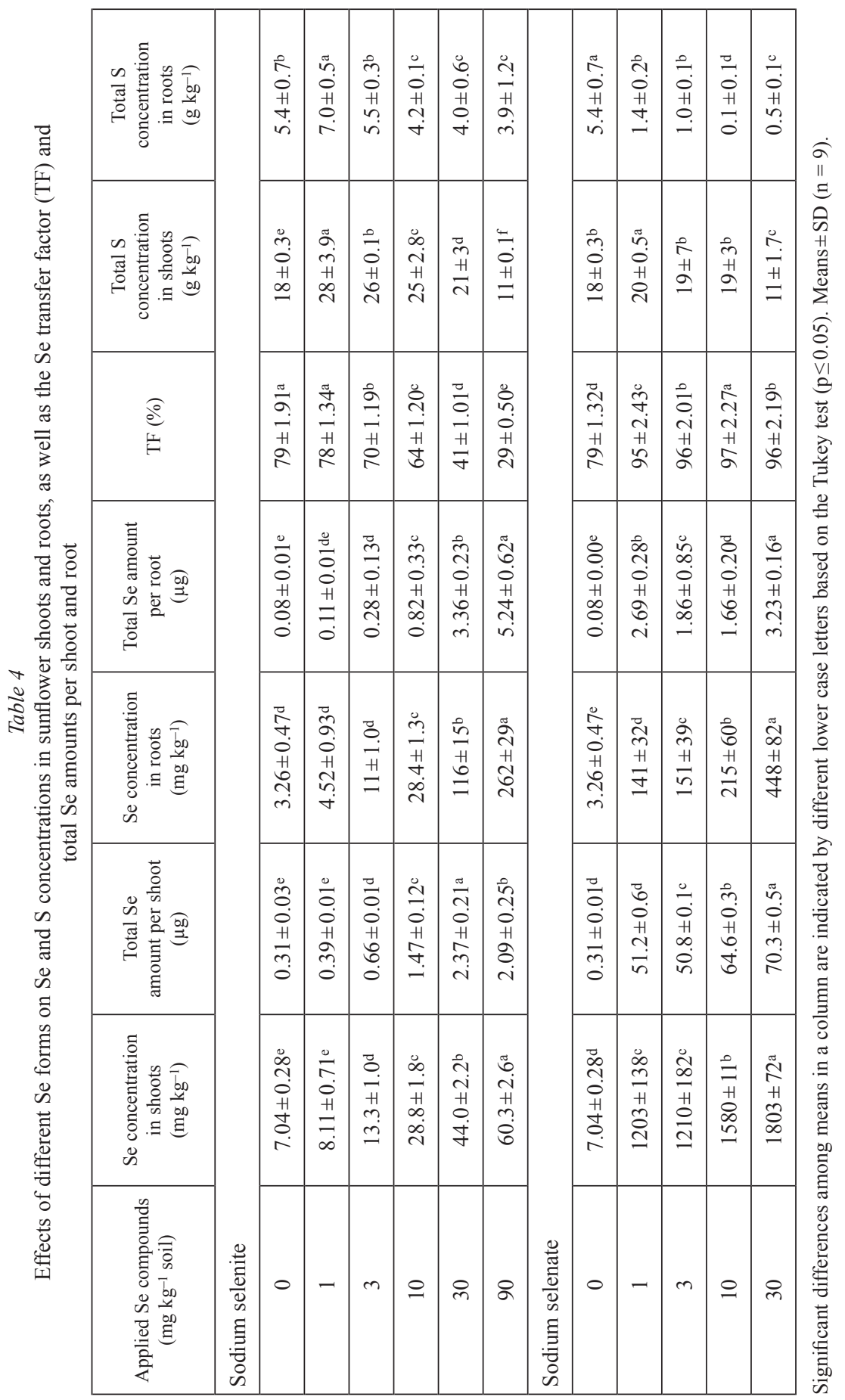

Acta Biologica Hungarica 69, 2018 


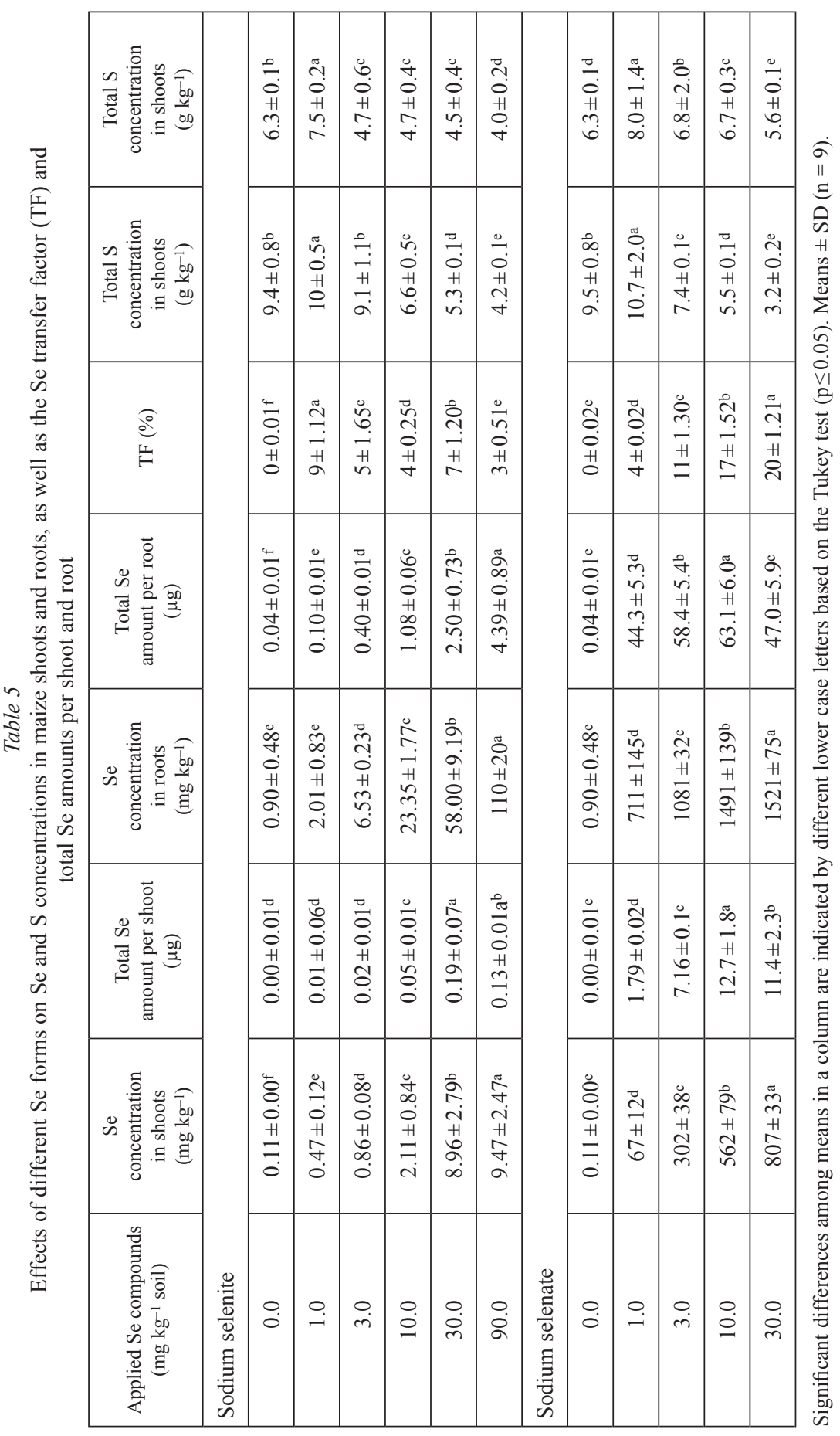

Acta Biologica Hungarica 69, 2018 
The calculated value of the Se transfer factor (a proportion of total plant Se found in shoots) decreased significantly with increasing rate of sodium selenite applied, in both sunflower and maize (Tables 4,5 ) but it remained relatively unaltered (sunflower, Table 4) or increased significantly (maize, Table 5) in the sodium selenate treatments. The Se transfer factor was greater in sunflower than maize regardless of the treatment, indicating a strong capacity of sunflower to transport Se from roots to shoots (Table 4). That strong Se-transporting capacity in sunflower was expressed to a greater extent in the sodium selenate than sodium selenite treatments.

The total S content in both plants' shoots and roots tended to decrease in response to both sodium selenite and sodium selenate increase; shoots had a higher amount of $\mathrm{S}$ than roots and this increase was significant in sunflower. However, the $1 \mathrm{mg} \mathrm{kg}^{-1}$ sodium selenite and sodium selenate treatments resulted in an increase in S content compared to the control treatments in both plants. Furthermore, sunflower shoots had much higher $\mathrm{S}$ content than maize shoots, while maize roots had more $\mathrm{S}$ content than sunflower roots in both the sodium selenite and sodium selenate treatments (Tables $4,5)$.

\section{DISCUSSION}

Our results agree with those obtained in previous works, which reported that Se application at low concentration may positively influence plant growth. In a pot experiment, Se-treated potato plants produced higher tuber yields than the control plants, a result which was related to the antioxidative effect of Se in delaying senescence [41]. Similarly, in a hydroponic experiment, the Se treatment was associated with a $43 \%$ increase in Brassica rapa seed production, which was attributed to increased total respiratory activity in leaves and flowers [24]. Foliarly-applied Se also increased the respiratory potential in young chicory plants [14]. Addition of Se significantly enhanced the antioxidant activity, antioxidant level and maize grain yield when drought stress level was increased [36].

Singh et al. [38] were the first authors to report about the positive effect of Se on plant growth. They showed the application of $0.5 \mathrm{mg} \mathrm{kg}^{-1} \mathrm{Se}$, as selenite stimulated the growth and dry matter yield of Indian mustard (Brassica juncea L.). They also found that Se applied in low concentrations can increase the growth and antioxidative volume of both mono- and dicotyledonous plants. Hartikainen et al. [17] demonstrated a positive response of lettuce (Lactucasativa L.) growth to Se, while Djanaguiraman et al. [7] obtained the same results in case of to soybean (Glycine max L.). At a higher supplementation level than $29 \mathrm{mg} \mathrm{kg}^{-1}$ soil, Se inhibited the growth and germination of tomato, lettuce, and radish (Raphanus sativus L.) seeds [4]. Hence, Se has an effect on germination. But according to Hasanuzzaman et al. [16] the positive effect on germination was linked to antioxidative activity, and selenite improved germination of bitter gourd (Momordica charantia L.) seeds at sub-optimal temperatures [5]. Depending on the plant species, growth stage, and plant organs, Se uptake and metabolism will be different. Broccoli (Brassica oleracea var. italica) is 
known for its ability to accumulate high levels of Se, with a greater number of the selenoamino acids in the form of Se-Met (SeMeSeCys) [23]. What we can conclude from all the results is as follows. The physiological importance of Se for higher plants could be evaluated within the following topics: anti-oxidative and pro-oxidative effects of Se and the role of Se under abiotic stresses.

Increasing concentrations of $\mathrm{Se}$ in a growth media can evoke an increase in $\mathrm{Se}$ content in crop plants [3]. In our experiments, the total Se concentrations in sunflower and maize increased in a dose-dependent manner after Se addition. It is well known that selenate is more easily transferred from the root to aboveground organs than selenite or organic Se, since much of selenite is retained in the root tissues, where it is rapidly transformed into organic Se compounds [45].

In nonhyperaccumulator species $\mathrm{Se}$ is thought to be accumulated nonspecifically by the sulfate transport system $[30,43]$. There is overwhelming evidence that sulfate transporters also transport selenate: mutants with nonfunctional sulfate transporter genes show selenate resistance $[37,43]$ and overexpression of a sulfate transporter led to an increase in selenate uptake [40]. Also, Se competes with S for uptake into plant roots [46]. In nonhyperaccumulators the sulfate transporters have not been reported to have a preference for sulfate over selenate. Thus, their activity affects the uptake of Se and S alike, explaining the observed correlation between tissue Se and S levels. In hyperaccumulators one or more sulfate transporters may have evolved into Se-specific transporters, as suggested by the 100 -fold higher Se-S ratio in these plants. The preferential uptake of Se appears to be at the cost of S, as suggested by the observed negative correlation between tissue $\mathrm{S}$ and Se levels. In this experiment, the high internal Se levels may be sensed by the plants as S, leading to the downregulation of the nonspecific $\mathrm{S}$ transporters, causing a decrease in $\mathrm{S}$ accumulation as plant Se accumulation via the Se specific transporter continues.

Finally in our study, the poor translocation of applied Se as sodium selenite from root to shoot was also found, since under sodium selenite exposure, plants accumulated great amounts of Se in their roots. The Se content in the shoots of sunflower was higher than that in the roots in all of the sodium selenate treatments, while this finding was not consistent for sodium selenate maize treatments.

\section{CONCLUSIONS}

The maximum Se concentration in sunflower shoots reached $1.8 \mathrm{~g} \mathrm{Se} \mathrm{kg}^{-1}$ in the sodium selenate-treated soil; therefore, sunflower could be classified as a Se hyperaccumulator. Translocation of sodium selenate from roots to shoot was significantly greater in sunflower than maize. There was a direct relation between Se and S concentrations in roots and shoots of both maize and sunflower. Our future work should concentrate on growing sunflower in Se-enriched soils to test biofortification of sunflower grain and oil, which are important from the points of view of the economy and human health. 


\section{ACKNOWLEDGEMENT}

We would like to thank the Institute of Crop Sciences of the University of Debrecen for its help to set up these experiments.

\section{REFERENCES}

1. Boyd, R. (2011) Selenium stories. Nat. Chem. 3, 570.

2. Broadley, M. R., Alcock, J., Alford, J., Cartwright, P., Foot, I., Fairweather-Tait, S. J., Hart, D. J., Hurst, R., Knott, P., McGrath, S. P., Meacham, M. C., Norman, K., Mowat, H., Scott, P., Stroud, J. L., Tovey, M., Tucker, M., White, P. J., Young, S. D., Zhao, F.-J. (2010) Selenium biofortification of highyielding winter wheat (Triticum aestivum L.) by liquid or granular Se fertilisation. Plant. Soil. 332, $5-18$.

3. Broadley, M. R., White, P. J., Bryson, R. J., Meacham, M. C., Bowen, H. C., Johnson, S. E., Hawkesford, M. J., McGrath, S. P., Zhao, F. J., Breward, N., Harriman, M., Tucker, M. (2006) Biofortification of UK food crops with selenium. Proc. Nutr. Soc. 65, 169-181.

4. Carvalho, K. M., Gallardo-Williams, M. T., Benson, R. F., Martin, D. F. (2003) Effects of selenium supplementation on four agricultural crops. J. Agric. Food Chem. 51, 704-709.

5. Chen, C. C., Sung, J. M. (2001) Priming bitter gourd seeds with selenium solution enhances germinability and antioxidative responses under suboptimal temperature. Physiol. Plant. 111, 9-16.

6. de Souza, M. P., Chu, D., Zhao, M., Zayed, A. M., Ruzin, S. E., Schichnes, D., Terry, N. (1999) Rhizosphere bacteria enhance selenium accumulation and volatilization by Indian mustard. Plant Physiol. 119, 565-573.

7. Djanaguiraman, M., Durga, D. D., Shanker, A. K., Sheeba, J. A., Bangarusamy, U. (2005) Selenium, an antioxidative protectant in soybean during senescence. Plant Soil 272, 77-86.

8. Duran, P., Acuna, J. J., Jorquera, M. A., Azcon, R., Paredes, C., Rengel, Z., de la Luz Mora, M. (2014) Endophytic bacteria from selenium-supplemented wheat plants could be useful for plant-growth promotion, biofortification and Gaeumannomyces graminis biocontrol in wheat production. Biol. Fertil. Soils 50, 983-990.

9. Facompre, N., El-Bayoumy, K. (2009) Potential stages for prostate cancer prevention with selenium: implications for cancer survivors. Cancer Res. 69, 2699-2703.

10. FAO (1998) World reference base for soil resources. Rome, Italy.

11. Fernández-Martínez, Charlet, L. (2009) Selenium environmental cycling and bioavailability: a structural chemist point of view. Rev. Environ. Sci. Bio. 8, 81-110.

12. Fordyce, F. M. (2012) Selenium deficiency and toxicity in the environment. In: Selinus, O., Alloway, B. J., Centeno, J. A., Finkelman, R. B., Fuge, R., Lindh, U., Smedley, P. (eds) Essentials of Medical Geology. Revised Edition. Springer, pp. 375-416.

13. Galinha, C., Sanchez-Martinez, M., Pacheco, A. M. G., Freitas, Md. C., Coutinho, J., Macas, B., Almeida, A. S., Perez-Corona, M. T., Madrid, Y., Wolterbeek, H. T. (2015) Characterization of selenium-enriched wheat by agronomic biofortification. J. Food Sci. Technol. 52, 4236-4245.

14. Germ, M., Stibilj, V., Osvald, J., Kreft, I. (2007) Effect of selenium foliar application on chicory (Cichorium intybus L.). J. Agric. Food Chem. 55, 795-798.

15. Govasmark, E., Salbu, B. (2011) Translocation and re-translocation of selenium taken up from nutrient solution during vegetative growth in spring wheat. J. Sci. Food Agric. 91, 1367-1372.

16. Hasanuzzaman, M., Hossain, M. A., Masayuki, F. (2010) Selenium in higher plants: physiological role, antioxidant metabolism and abiotic stress tolerance. J. Plant Sci. 5, 354-375.

17. Hartikainen, H., Ekholm, P., Piironen, V., Xue, T., Koivu, T., Yli-Halla, M. (1997) Quality of the ryegrass and lettuce yields as affected by selenium fertilization. Agric. Food Sci. Finl. 6, 381-387.

18. Hartikainen, H., Xue, T. (1999) The promotive effect of selenium on plant growth as triggered by ultraviolet irradiation. J. Environ. Qual. 28, 1372-1375. 
19. Hawrylak-Nowak, B. (2013) Comparative effects of selenite and selenate on growth and selenium accumulation in lettuce plants under hydroponic conditions. Plant Growth Regul. 70, 149-157.

20. Ingh, M. (2005) A review on phytoremediation of heavy metals and utilization of its byproducts. Appl. Ecol. Env. Res. 3, 1-18.

21. Kovács, B., Győri, Z., Prokisch, J., Loch, J., Dániel, P. (1996) A study of plant sample preparation and inductively coupled plasma emission spectrometry parameters. Commun. Soil Sci. Plant Anal. 27, 1177-1198.

22. Longchamp, M., Angeli, N., Castrec-Rouelle, M. (2011) Uptake of selenate and/or selenite in hydroponically grown maize plants and interaction with some essential elements (calcium, magnesium, zinc, iron, manganese, and copper). In: Bañuelos, G. S., Lin, Z.-Q., Yin Xuebin, Duan Ning (eds) Selenium (Global perspectives of impacts on humans, animals and the environment). University of Science and Technology of China Press, Hefei, China, pp. 83-89.

23. Lyi, S. M., Heller, L. I., Rutzke, M., Welch, R. M., Kochian, L. V., Li, L. (2005) Molecular and biochemical characterization of the selenocysteine Se-methyltransferase gene and Se-methylselenocysteine synthesis in broccoli. Plant Physiol. 138, 409-420.

24. Lyons, G. H., Genc, Y., Soole, K., Stangoulis, J., Liu, F., Graham, R. D. (2009) Selenium increases seed production in Brassica. Plant Soil 318, 73-80.

25. Lyons, G. H., Lewis, J., Lorimer, M. F., Holloway, R. E., Brace, D. M., Stangoulis, J. C., Graham, R. D. (2004) High-selenium wheat: agronomic biofortification strategies to improve human nutrition. J. Food Agric. Environ. 2, 171-178.

26. Mao, H., Wang, J., Wang, Z., Zan, Y., Lyons, G., Zou, C. (2014) Using agronomic biofortification to boost zinc, selenium, and iodine concentrations of food crops grown on the loess plateau in China. J. Soil Sci. Plant Nutr. 14, 459-470.

27. Méplan, C., Hesketh, J. (2012) The influence of selenium and selenoprotein gene variants on colorectal cancer risk. Mutagen. 27, 177-186.

28. Nagy, K., Lévai, L., Kovács, B. (2010) The effect of selenium supply on maize and sunflower. Növénytermelés 59, 61-84. (In Hungarian)

29. Pennanen, A., Xue, T., Hartikainen, H. (2002) Protective role of selenium in plant subjected to severe UV irradiation stress. J. Appl. Bot. 76, 66-76.

30. Persans, M. W., Salt, D. E. (2000) Possible molecular mechanisms involved in nickel, zinc, and selenium hyperaccumulation in plants. Biotechnol. Eng. Rev. 17, 389-413.

31. Pilon-Smits, E. A., Quinn, C. F., Tapken, W., Malagoli, M., Schiavon, M. (2009) Physiological functions of beneficial elements. Curr. Opin. Plant Biol. 12, 267-274.

32. Poblaciones, M. J., Rodrigo, S., Santamaría, O., Chen, Y., McGrath, S. P. (2014) Selenium accumulation and speciation in biofortified chickpea (Cicer arietinum L.) under Mediterranean conditions J. Sci. Food Agric. 94, 1101-1106.

33. Poblaciones, M. J., Rodrigo, S. M., Santamaría, O. (2013) Evaluation of the potential of peas (Pisum sativum L.) to be used in selenium biofortification programs under Mediterranean conditions. Biol. Trace Elem. Res. 151, 132-137.

34. Puskás-Preszner, A., Kovács, B. (2009) Effect of molybdenum treatment in a long-term field experiment influencing on the element uptake of plant and molybdenum fractions of soil. Agrártudományi Közlemények 36, 117-122. (In Hungarian)

35. Rayman, M. P. (2008) Food-chain selenium and human health: emphasis on intake. Br. J. Nutr. 100, 254-268.

36. Sajedi, N., Ardakani, M., Madani, H., Naderi, A., Miransari, M. (2011) The effects of selenium and other micronutrients on the antioxidant activities and yield of corn (Zea mays L.) under drought stress. Physiol. Mol. Biol. Plants 17, 215-222.

37. Shibagaki, N., Rose, A., McDermott, J. P., Fujiwara, T., Hayashi, H., Yoneyama, T., Davies, J. P. (2002) Selenate-resistant mutants of Arabidopsis thaliana identify Sultr1;2, a sulfate transporter required for efficient transport of sulfate into roots. Plant J. 29, 475-486. 
38. Singh, M., Singh, H., Bhandari, D. K. (1980) Interaction of selenium and sulphur on the growth and chemical composition of raya. Soil Science 129, 238-244.

39. Tamaoki, M., Freeman, J. L., Pilon-Smits, E. A. H. (2008) Cooperative ethylene and jasmonic acid signaling regulates selenite resistance in Arabidopsis. Plant Physio. 146, 1219-1230.

40. Terry, N., Zayed, A. M., de Souza, M. P., Tarun, A. S. (2000) Selenium in higher plants. Annu. Rev Plant Physiol. Plant Mol. Biol. 51, 401-432.

41. Turakainen, M. (2007) Selenium and its effects on growth, yield and tuber quality in potato University of Helsinki, Helsinki, PhD. Thesis.

42. Turakainen, M., Hartikainen, H., Ekholm, P., Seppänen, M. M. (2006) Distribution of selenium in different biochemical fractions and raw darkening degree of potato (Solanum tuberosum) tubers supplemented with selenate. Agric. Food Chem. 54, 8617-8622.

43. White, P. J., Bowen, H. C., Parmaguru, P., Fritz, M., Spracklen, W. P., Spiby, R. E., Meacham, M. C., Mead, A., Harriman, M., Trueman, L. J., Smith, B. M., Thomas, B., Broadley, M. R. (2004) Interactions between selenium and sulphur nutrition in Arabidopsis thaliana. J. Exp. Bot. 55, 19271937.

44. Xue, T., Hartikainen, H., Piironen, V. (2001) Antioxidative and growth-promoting effect of selenium on senescing lettuce. Plant Soil 237, 55-61.

45. Zayed, A., Lytle, C. M., Terry, N. (1998) Accumulation and volatilization of different chemical species of selenium by plants. Planta 206, 284-292.

46. Zayed, A., Terry, N. (1992) Selenium volatilization as influenced by sulfate supply. J. Plant Physiol. 140, 646-652. 